\title{
New pathways for governing food system transformations: a pluralistic practice-based futures approach using visioning, back-casting, and serious gaming

\author{
$\underline{\text { Astrid C. Manghus }}^{1,2}, \underline{\text { Joost M. Vervoort }}{ }^{1,3,4}, \underline{\text { Steven R. McGreevy }}^{4}, \underline{\text { Kazuhiko Ota }}^{4}, \underline{\text { Christoph D. D. Rupprecht }}^{4}, \underline{\text { Momoe Oga }}^{4}$ \\ and Mai Kobayashi ${ }^{4}$
}

\begin{abstract}
The global environmental change that characterizes the Anthropocene poses a threat to food systems. Cities increasingly serve as the spaces where civil society, private actors, and local governments come together to strategize toward more sustainable food futures and experiment with new forms of food governance. However, much of the futures literature in the context of sustainability focuses on large-scale, global scenarios. These are important pieces of knowledge, but they often do not effect a change in local perspectives and practices. In this paper we respond to the need for novel futures approaches to help urban coalitions of societal actors create pathways to sustainability transformations. We investigate how existing examples of good practices, or "seeds," can be used to open up novel, desirable, bottom-up futures in the case study of Kyoto (Japan). Innovative combinations of methodologies (visioning, back-casting, simulation games) are used and assessed in order to create multiple ways of experimenting and engaging with food system futures. Our results consist of a pluriform pathway to a sustainable Kyoto food system. Each method brings in its unique pathway elements: visioning to formulate a desired end goal, back-casting to create a step-by-step action plan, and gaming to practice with the future. The combination of Kyoto-based "seeds" with initiatives from elsewhere and with a new food system governance model (a food policy council) resulted in participants learning about new food system practices, extending their networks, and support for actualizing a food policy council. We conclude that multimethod futures processes that combine existing practices and new modes of governance are a promising new way to outline various pathways for sustainability transformations.
\end{abstract}

Key Words: Anthropocene; futures methods; imaginaries; sustainability transformations; urban food systems

\section{INTRODUCTION}

Urban food systems are under pressure from both global urbanization and environmental change. Currently, over $50 \%$ of the world's population lives in urban areas, and by 2050 this is projected to reach $66 \%$ (United Nations 2015). A new set of challenges arises from the need to feed this increasing number of city dwellers in the context of the Anthropocene: the current geological epoch in which human impacts on earth system processes have become so extreme that humanity can be considered a major geological force (Crutzen 2002). Following the FAO (2011), an urban food system can be defined as all biological processes and physical infrastructure involved in feeding an urban population. It is influenced by the social, political, economic, and environmental contexts in which it operates, and interacts with the ecological and human environment in which it is located. The challenges facing urban food systems in the Anthropocene are complex and consist of intertwined drivers and phenomena across biophysical and social domains, posing threats to local ecosystems, public health, community, and social justice. This demonstrates the urgency but also the complexity of transformative food systems change toward sustainability (Bai et al. 2016).

Cities themselves increasingly serve as the spaces in which to bring together civil society, private actors, and local governments, and experiment with new forms of food governance (Moragues-Faus and Morgan 2015). However, governing transformations toward more sustainable urban food futures first requires that those futures can be imagined. The urban Anthropocene poses significant challenges to the abilities of people worldwide to imagine novel, plausible, actionable, and diverse urban food futures. Although the field of futures studies offers methodologies for systematic and explicit thinking about alternative futures (Bell 1996), many of the future pathways imagined for a better world in the Anthropocene focus on global or regional levels with lowresolution analyses and a strong focus on quantitative methods. In such pathways, there is generally very little direct connection to the plurality of on-the-ground practices and realities around the world (Smit and Wandel 2006, Bai et al. 2016), which results in a lack of opportunities for engaging with the more diverse bottom-up futures that can emerge from them (Bennett et al. 2016).

Realizing truly novel, but grounded and pluralistic Anthropocene food futures requires a change in human values, assumptions, cultures, worldviews, and power relations (Bennett et al. 2016). One concept that captures all these elements is the notion of social imaginaries: collectively held spaces of the imagination that form the most general political and social parameters through which people perceive, judge, and act in the world (Steger 2008). To guide attitudes, choices, and actions toward desirable futures, the "Seeds of Good Anthropocenes" initiative identifies "seeds": practices that strive for desirable Anthropocene futures currently operating at the margins globally, but that, under the right circumstances, have the potential to scale up, change dominant imaginaries, and contribute to making better futures. The researchers involved in this initiative argue that this can be done by using existing successful small-scale alternatives to map people's desires, the

${ }^{1}$ Copernicus Institute of Sustainable Development, Utrecht University, ${ }^{2}$ Urban Futures Studio, Utrecht University, ${ }^{3}$ Environmental Change Institute, University of Oxford, ${ }^{4}$ FEAST Project, Research Institute for Humanity and Nature, Kyoto 
reasons for the success of specific alternatives as inspiration, combining them to generate holistic alternative futures rooted in the present (Bennett et al. 2016).

Building on this "seeds" approach, we report on efforts to create and apply a bottom-up futures process that is practice-based and pluralistic at its core. Innovative combinations of methodologies (visioning, back-casting, serious games) were used to enable a cocreation of diverse yet grounded future pathways. These novel types of content and combination of methods contributed to the creation of futures that were new to the participants - food system actors in Kyoto, Japan - and allowed for links between new futures and concrete action toward achieving them to be seen. Using these experiments as a lens, we show how bottom-up, pluralistic futures processes generated by successful existing alternative practices can outline answers to food system challenges in the Anthropocene. This also provides insights on the application of specific futures methods in such a process.

\section{THEORETICAL BACKGROUND}

\section{Extending urban food imaginaries}

To understand the complex set of drivers behind food practices in cities and begin to imagine new food system futures, it is important to acknowledge that food is not only a material condition that exists in people's lives, but is a vital element in their lifeworlds: the subjective perspective of every individual on their life conditions (Kraus 2015). Social imaginaries influence the structuration of society through legal and institutional interventions, such as the shape of markets and bureaucracies. Shared conceptions of desirable and possible futures are a part of these social imaginaries, and their enactment affects decisions in the present (Jasanoff 2015). The imaginable futures that are a part of social imaginaries thus drive societies in certain directions by shaping common practices, communal attachments, and institutional arrangements (Steger 2008). An example with regard to food in cities is the recent rise of urban agriculture in both discourse and practice (Mayes 2014). In this paper, we will investigate how social imaginaries may be extended using new combinations of futures methods.

\section{Combining the seeds approach with a new mode of governance}

Bennett et al. (2016:442) define "seeds" as "initiatives (social, technological, economic, or social-ecological ways of thinking or doing) that exist, at least in prototype form, and that represent a diversity of worldviews, values, and regions, but are not currently dominant or prominent in the world." To identify and highlight such initiatives, the Seeds of Good Anthropocenes database and web site was launched (https://goodanthropocenes.net/showcase/ seed-collection/), with the intention of using the seeds as building blocks to create novel, desirable futures (Bennett et al. 2016). Thus far, such bottom-up futures have largely been created through the combining of different seeds into new ideas (Pereira et al. 2018a, $b$ ). Many of the seeds in the database are directly relevant to changing food systems; and because cities are hubs for innovation, many seeds have focused on change in urban settings as well (Seto and Ramankutty 2016). We aim to build on current efforts that use seeds to create new futures by not only combining seed initiatives, but also having the seeds interact with new governance conditions that allow them to flourish. This is an important contribution to the seeds approach, because such experimentation can act as practice or preparation for actual shifts in governance that encourage bottom-up-led change.

We use food policy councils (FPCs) as the mode of governance with which seeds interact. FPCs are organizations in which actors with different roles in local, municipal, or state-level food systems come together driven by aspirations for food system change (Mooney et al. 2014). Many cities in the U.S. and Canada, such as Minneapolis and Toronto, have active FPCs. In countries like Japan they are not as common. FPCs differ in the ways in which they are legally recognized. Existing FPCs are for example organized as independent action groups, NGOs, or fully embedded government bodies (Schiff 2008). There are some standard FPC activities that most have in common: building partnerships with stakeholders, examining current policies, and generating new policy ideas related to food, and by supporting or creating programs that address food system issues (Scherb et al. 2012). Mooney et al. (2014:234) describe FPCs as "“spatially embedded" incubators that extend participation in an expansive range of experimentation in policy and practice." As such, they constitute a useful mode of governance for the various food system actors in this study and their seeds practices. In the context of an FPC, they can collectively develop strategies toward a variety of desirable, plausible futures.

\section{Mobilizing complementary futures methods}

The combination of seed initiatives with a new mode of governance is the first element in our pluralistic, bottom-up approach to urban food futures; the second is the use of different complementary methods to imagine and experiment with such futures. Pluralism in methods as well as in content and perspectives is a core principle of pluralistic systems thinking (Gregory 1996, Vervoort et al. 2015). An approach aimed at opening up imaginaries to new futures is expected to benefit from the use of multiple futures methods as well as diverse reference points for content, because different futures methods allow for entirely different ways to engage with and create futures (Popper 2008). Most combinations of futures methods so far have focused on complementary variations of looking ahead (through visioning, step-wise strategy development such as back-casting and systems analysis). We propose that by combining multiple complementary futures methods, planning-oriented foresight methods can be enriched with an entirely different type of engagement, inhabiting, practicing, and experimenting with the future.

\section{Experimenting with urban food futures}

For the urban environment, Daffara (2011) argues that the envisioning of future cities enables communities to create a pull toward a preferred future because the collective creation and discussion of a shared future vision can improve processes to head toward this vision, while also keeping the process agile so it can accommodate "waves of urban change" in the city's cultural, structural, technical, and other environments. Seto and Ramakutty (2016) describe how there is a need for studies that go beyond matching supply to demand, and consider urbanization and food systems jointly. Production, processing, packaging, distribution, and consumption at the table are all changing in the urbanizing Anthropocene. This also means a change in tastes, social interactions, food cultures, and values (Seto and Ramakutty 2016). In this change process, futures methods can 
assist actors from all sections of the food system in both the conceptualization and initiation of transformations to sustainability. In a futures process, the various actors can shape the futures they desire and collectively think through the pathways and plans to realize them (Hebinck et al. 2018). By mobilizing cities as laboratories (Wigginton et al. 2016), we hypothesize that this paper can highlight existing good practices that, when combined, can show outlines of sustainable food futures.

\section{METHODS}

In our study, we utilized a combination of visioning, back-casting, and serious gaming in the context of seeds and a new governance structure. The three methods were selected because they have specific qualities in common: vision-driven planning, nonconsequentiality, the provision of an experiential environment, and interaction with others in the case of backcasting and gaming. To test this approach, a combination of visioning, back-casting, and gaming was applied to the case study of Kyoto (Japan).

\section{Case description}

Japan's national trends of aging, slowly changing gender roles, and overconsumption of biocapacity are mirrored in Kyoto's urban food system. In the Kyoto basin, in which the city is located, overall population is trending downward and farmland has been converted to other uses at a rate of $10 \%$ in the past 10 years (Oda et al. 2018). Kyoto prefecture's food self-sufficiency rate (calorie base) is a mere $12 \%$ (Ministry of Agriculture, Forestry and Fisheries 2017). Despite this backdrop, there are many reasons for choosing Kyoto as a candidate for leading innovative urban food system change.

Kyoto City is considered the cultural center of Japan. Numerous temples and shrines gave rise to a rich food culture represented by sophisticated cooking styles such as "kyo-kaiseki-ryori," along with traditional vegetable varieties developed and celebrated in Kyoto known as "kyoyasai." The city prides itself on being environmentally forward thinking as the site where the Kyoto Protocol was signed in 1997. A study commissioned by the city government found that Kyoto's ecological footprint was $10 \%$ smaller than that of Japan as a nation, primarily because of smaller living spaces and less motor vehicle use (World Wildlife Fund Japan 2016). The same study pointed to food consumption as Kyoto's second largest contributor to its ecological footprint, composing 24\% of the total (World Wildlife Fund Japan 2016). A recent survey shows Kyoto residents favor using space in a shrinking Kyoto for urban agriculture and leisure (Rupprecht 2017).

These reasons make Kyoto an ideal candidate for this study and also a place that can gain from imagining innovative sustainable futures. It is plausible that the Kyoto case could yield relevant results not just for other shrinking Japanese cities, but for other countries projected to follow a similar trajectory in the upcoming decades as well, e.g., South Korea. The literature on transition movements, renewable energy, and participatory processes details many cases in Europe, the UK, and North America, but is comparatively sparse when it comes to Japan and sites in Asia. It is therefore interesting to see what kind of results the proposed methods generate, and how well they work in the Japanese governance context.

\section{Methodological background}

Before detailing the methodology for the Kyoto case study, we elaborate on the background information of the three futures methods in general. A vision is the collective image of what a community wants to be like, and how it wants to look at a given point in the future (D'Hondt 2012). O'Brien and Meadows (2001:497) describe that visioning methodologies often, and necessarily differ from case to case, depending on the "stories to tell or the process to sell." However, they identified four key characteristic dimensions underlying every visioning process (Table 1). In back-casting, a series of steps map out an action plan, starting from a vision and working back to the present (Voros 2006). This enables participants to collectively assess vulnerabilities and aspirations, and define shared adaptation goals and action (Faldi and Macchi 2017). There is another mode of engaging with the future that these combinations do not cover: practicing and experimenting with the future through games. Serious games are games that "intend to fulfill a purpose beyond the self-contained aim of the game itself" (Mitgutsch and Alvarado 2012:121). They rely on playful engagement with potential futures but use this process of engagement to develop new thoughts and ideas about possible solutions for a problem at hand (Davies et al. 2012). Games can take many forms, from a narrative only to a very elaborate board game, with varying levels of technical complexity. The elements that most games have in common are a game space, set boundaries, rules for interaction and artifacts, and a goal to be achieved by the players (Gray et al. 2010).

Table 1. Key vision characteristics (from O'Brien and Meadows 2001).

\begin{tabular}{ll}
\hline \hline Key characteristic & Definition for fieldwork \\
\hline 1 Current situation & $\begin{array}{l}\text { The interviewee's current situation in terms of } \\
\text { core competencies, available resources, strengths, } \\
\text { and weaknesses; as well as the pathway to their } \\
\text { current position. } \\
\text { Unconstrained design: participants are permitted } \\
\text { to change any of the containing systems in their } \\
\text { vision. Possible fellow stakeholders are identified. } \\
\text { environment }\end{array}$ \\
$\begin{array}{l}\text { One vision centered around a sustainable food } \\
\text { Desired future } \\
\text { state }\end{array}$ & $\begin{array}{l}\text { system in 2050. } \\
\text { Any possibilities the participant gives for relating, } \\
\text { future }\end{array}$ \\
contrasting, or connecting the vision to the \\
state
\end{tabular}$\quad \begin{aligned} & \text { present. } \\
& \end{aligned}$

In recent years, visioning and back-casting have been combined with other methods using exploratory scenarios for the purpose of testing plans against contextual challenges (Kok et al. 2011, Avin 2012, Vervoort et al. 2014), with conceptual modeling (Van Vliet et al. 2012) and with new technologies such as digital tools and datasets that give real-time feedback and visualization of the back-casting plans (Robinson et al. 2011). From these combinations and technologies, new possibilities arise for a complementary approach with gaming. The experiential aspect of especially multiplayer role-playing games allows for the concrete and abstract sharing of experience (Kolb 1984), which can help bring new aspects of shared imaginaries to life. A mixed methods approach is of key importance for capturing these synergies. 


\section{Experimental design}

Figure 1 provides a complete overview of the mixed-methods design applied in the Kyoto case. The methods feed into each other in different ways: visioning outcomes are used as the base for the back-casting focus groups, and in determining participants; initiatives are used as seeds in the card game. In addition to these methodological synergies, the methods also generate different futures. With regard to the pathway elements that each method generates, we designed the visioning exercises as interviews to capture in-depth, personal ideal futures: the end goal of an action plan for a sustainable Kyoto food system. The other methods enable planning for collective action and sharing of knowledge. The visioning interviews were set up as individual interviews, while back-casting and gaming was done in group exercises. The back-casting focus groups outlined the step-by-step processes in various action plans. The two games allow participants to experiment with realistic conditions, actor constellations, and forms of governance. Their role-play elements also allow players to take on the roles of other food system actors, possibly increasing the empathy they feel for them.

Fig. 1. Conceptual model of method design.

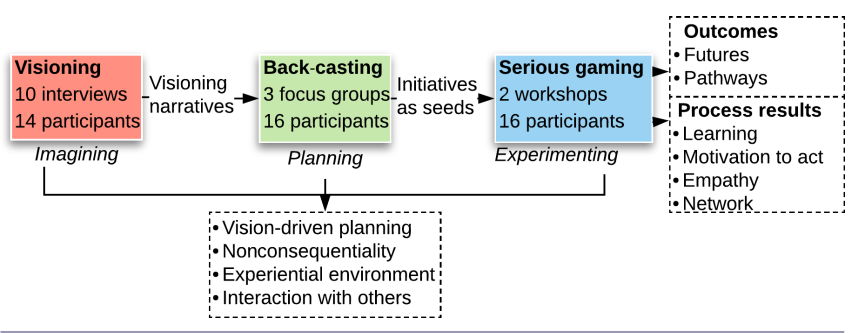

The target pool of participants consisted of actors from all elements of Kyoto's food system (production, distribution, consumption, waste management, education, and policy making). They had to be affiliated with an initiative that could qualify as a seed. The first group of participants was recruited from a pool of participants in two seminars on food policy councils in the U.S. and Canada, organized by the Kyoto-based FEAST research project on agrifood systems in transition. The research project approached this first group of participants. Through the participants themselves, other contacts were recruited to participate as well. Missing food system elements in this group, e.g., waste management, were subsequently filled by the research team. They cold-emailed a number of people engaging with these topics, who were sourced from local organizations or platforms such as World Wide Opportunities on Organic Farms (WWOOF) that connect volunteers and organic farms.

\section{Visioning: creating images of desired futures}

The first method in the complementary futures approach was a set of semistructured individual visioning interviews $(\mathrm{Qu}$ and Dumay 2011). The literature on visioning processes provided a number of guidelines on which the interview questions were based. First, visioning processes try to uncover the participants' desired future for the long-term, which is generally considered to be about 30 years in the future. Choosing this time horizon offers participants the possibility to reconsider elements of their legal and social systems in which they are deeply embedded (Soria-
Lara and Banister 2017). Based on this, 2050 was chosen as the time horizon for the visioning in this study. The second step in the process is to identify barriers to and opportunities for reaching the desired future that is being described (O'Brien and Meadows 2001).

The set of questions that guided the interviews for this study were designed around three topics: (1) the interviewee's ideal food future for Kyoto prefecture in 2050; (2) the people that she or he thought should be involved in this vision; (3) and the main issues that have to be resolved in the present in order to realize the future vision. The four key characteristics were referenced as the main labels for coding the interview data for analysis.

\section{Back-casting: collective planning toward visions}

The second futures method, back-casting, was designed to plan for the futures outlined in the visioning interviews. The backcasting exercises took place in a series of three focus groups. A professional external facilitator led all three sessions. At the start of each focus group, the participants received a handout with three visioning narratives based on three main themes that emerged from the visioning interviews. It was communicated that these visions were based on real stories collected from participants in the group. Subsequently, the participants were invited to discuss all three narratives and to select the one that appealed to them the most. After a short discussion about their vision of choice, they wrote the elements that they thought were most relevant on one end of a roll of paper. From there, they worked back in time from the future by writing down and posting specific activities on yellow post-it notes, and blue post-its for the people to execute these plans. They were asked to be as specific as possible, and to work up to the present, ending with activities for "tomorrow." In addition to the output of the back-cast, participants were asked to fill out a reflective survey (Appendix 1).

\section{Serious games: experimenting with governing the future}

We applied games in three ways: as research method, group data collection method, and research object (Mayer et al. 2014). Two role-playing games were designed for use in the workshop: a digital game and a card-based live role-playing game. They are explained by their key game elements (Gray et al. 2010).

\section{Digital game: understanding food system connections}

The digital game was developed by Games and Interaction undergraduate students at the HKU University of the Arts in Utrecht, the Netherlands. It was the product of a week-long game jam and a subsequent two-month course, in which the initial concept was developed further. Game jams are "social events involving the integration of various game making disciplines ... to make games under constraints, such as a short fixed time" (Eberhardt 2016:34). The game that was developed, Let'sKyoto, was still a prototype when used and feedback to further improve and balance game mechanics was also sought in addition to educational effects. Let'sKyoto is a role-playing game with six roles: farmer, supermarket owner, local restaurant owner, fast food restaurant owner, high-income consumer, and low-income consumer (Fig. 2). The players take turns, navigating the food system in a simplified version of Kyoto. The farmer starts by planting crops and setting a price for the harvest. Subsequently, the supermarket, local restaurant, and fast food chains have to purchase food from suppliers. The local restaurant only has the option of buying from the farmer, but the other two businesses 
have the option of purchasing imported foods. After all three businesses make their purchase, the consumers feed themselves by purchasing four units of food each from a business of their choice. At the end of each round, the players all get one vote on one of three policy interventions: investing in more efficient crops (cheaper production costs for the farmer); tax fast food (increase the price for fast food); or tax overseas imports (costly for supermarket and fast food). Players have the option of choosing only in their best interests or striving for alternative goals, such as equal income distribution or a healthier food system. Table 2 gives an overview of the game, based on the key elements as formulated by Gray et al. (2010). Participants' personal experience was measured in a survey conducted immediately after playing the game (Appendix 2).

Fig. 2. Screenshot of digital game Let'sKyoto (English version).

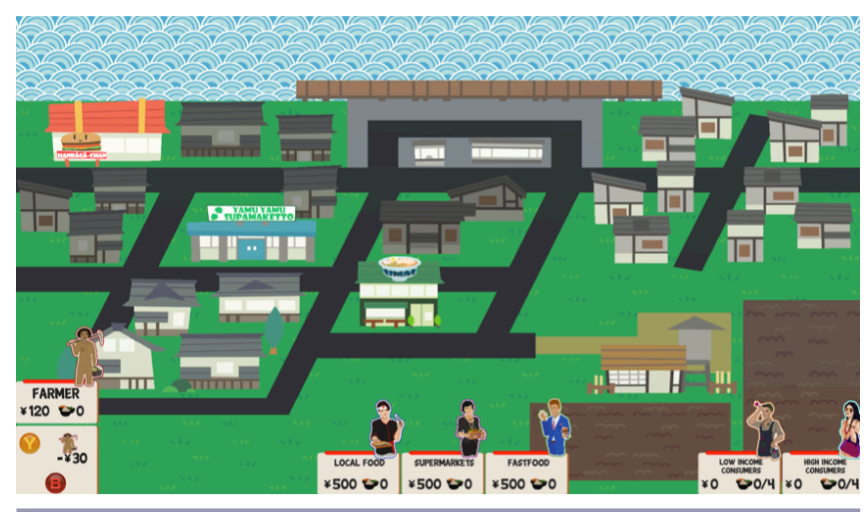

Table 2. Key elements of digital game Let'sKyoto (from Gray et al. 2010).

\begin{tabular}{|c|c|}
\hline Key element & Description \\
\hline 1 Game space & $\begin{array}{l}\text { A digital, nonmoving view of a stylized Kyoto } \\
\text { City and its surroundings. In this space, the rules } \\
\text { for interaction ( } 3 \text { ) apply. }\end{array}$ \\
\hline 2 Boundaries & $\begin{array}{l}\text { The game time is unlimited. The game space is a } \\
\text { digital static overview of a city. In reality, all } \\
\text { participants are seated together in front of a } \\
\text { screen. }\end{array}$ \\
\hline $\begin{array}{l}3 \text { Rules for } \\
\text { interaction }\end{array}$ & $\begin{array}{l}\text { The turns follow a set order, as does the voting } \\
\text { process. Participants can discuss at any point in } \\
\text { time. }\end{array}$ \\
\hline 4 Artifacts & In-game visual score representation. \\
\hline 5 Goal & $\begin{array}{l}\text { Use policy interventions to optimize the local food } \\
\text { system and ensure a fair share of the chain for all } \\
\text { involved. }\end{array}$ \\
\hline
\end{tabular}

\section{Card-based live role-playing game}

The second game was tailored specifically to the contexts uncovered in fieldwork conducted in Kyoto. The game took the form of a tabletop card-based live role-playing game (Fig. 3), which, in contrast to the digital game, lowered the barrier to play for participants of all backgrounds and ages. At the center of the game was a card deck of thirty real-world seeds from Kyoto prefecture, Japan, and the world. In line with the Seeds of Good Anthropocenes-approach, we hypothesized that including existing seed ideas in the game would enable participants to experiment freely with futures that are still grounded in existing practices. The first initiatives to be included in the game were the food-related seeds from the Seeds of Good Anthropocenes (2017) online database. Additional initiatives were sourced from the Japan for Sustainability database (http://www.japanfs.org/), Climate-KIC's Daily Planet newsletter database (https:// dailyplanet.climate-kic.org/), and from the interviewees.

Fig. 3. Seed and role cards for the card-based live role-playing game, The Food Policy Council Simulator.

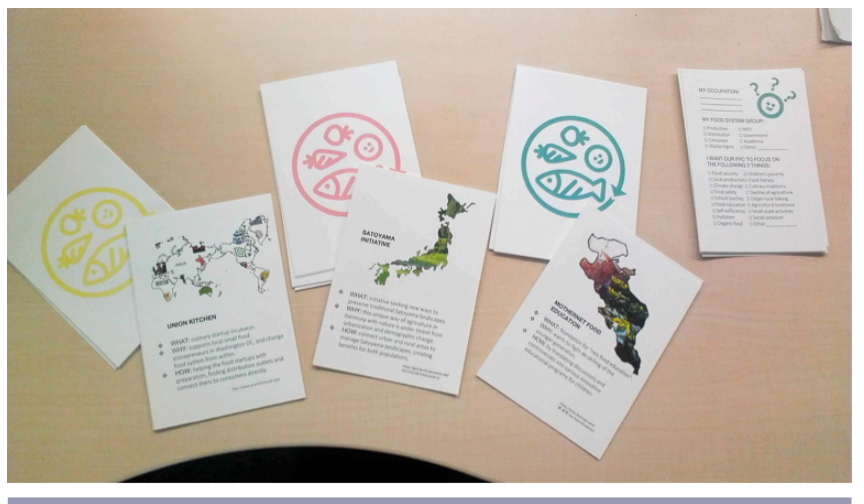

The Food Policy Council (FPC) Simulator game starts with all players filling out a role card for themselves based on their realworld occupation (see Appendix 3 for the detailed rules). Every player can select three main food-related issues on their role card that they think the FPC should address. These issues were based on outcomes of the visioning and back-casting exercises that had been conducted. During the introduction round, the facilitator writes down each player's priority issues on the FPC agenda sheet. Then, the FPC's first year begins. The members draw one card from each of the three seeds decks (examples from Kyoto, Japan, and the world) and share them with the group for creative inspiration (Appendix 4). They then should make a plan that includes the seed initiatives as is, or incorporates elements or reconceptions of the initiatives. The plan is written down, with a budget specification. Based on a quick assessment, the facilitator gives the FPC a feasibility percentage. Once the feasibility is set, the FPC has to roll a 20-sided dice to determine success or failure. In case of failure, the members should discuss plausible reasons why the failure occurred, spend some of their budget to improve their plan, and roll again. A final step at the end of each round is rolling for natural disasters, something that Japan is prone to experiencing, and deal with the aftermath and recovery if a disaster hits. The team with the highest number of successful initiatives wins. Table 3 gives an overview of the key characteristics of this card-based live role-playing game. To measure the participants' personal experience, perceived empathy, exposure to new ideas, and increased networking capacity, they were asked to fill out a survey after the game (Appendix 2).

\section{RESULTS}

The results of the different futures methods generated various sustainable food futures, as well as process effects that were reported back by participants in the surveys. 
Table 3. Key elements of card-based live role-playing game, The Food Policy Council (FPC) Simulator (from Gray et al. 2010)

\begin{tabular}{ll}
\hline \hline Key element & Description \\
\hline 1 Game space & $\begin{array}{l}\text { A round table with three to five participants. In } \\
\text { this space, the rules for interaction (3) apply. }\end{array}$ \\
The game time is 55 minutes per round. The game \\
space consists of a table around which the players \\
and facilitator are seated. All teams are situated in \\
the same room. \\
The facilitator has the final say over the game \\
proceedings. The players are free to discuss with \\
interaction & $\begin{array}{l}\text { the facilitator and one another throughout the } \\
\text { game. The chairperson is the leader and main }\end{array}$ \\
& spokesperson for the groups. \\
& Fictional yen in quantities of 50.000 and 100.000. \\
& 20-sided dice that has to be rolled to determine \\
& success, failure, and the occurrence of natural \\
& disasters. \\
& FPC agenda sheet that contains the main points of \\
& interest. \\
& Seeds cards with innovative food practices from \\
& Kyoto, Japan, and the world. \\
Role cards that contain the player's real-life or \\
imaginary role and her/his priorities. \\
Plan sheet that contains the plan and budget. \\
To generate as many successful plans as possible \\
within the time boundary (2), and by doing so, to \\
win against the other team(s).
\end{tabular}

\section{Visioning}

Each visioning interview started with the participants describing their current situation and the path that had led them there. To give a brief introduction before synthesizing all visions, Table 4 lists the participants and how they described their current position in their interview.

Table 4. Current positions of participants

\begin{tabular}{ll}
\hline \hline $\begin{array}{l}\text { Inter- } \\
\text { view }\end{array}$ & Current position \\
\hline 1 & $\begin{array}{l}\text { Graduate student at Kyoto University's Faculty of Agriculture. } \\
\text { Employee in the overseas division of a Kyoto-based organic } \\
\text { vegetable home-delivery distributor. }\end{array}$ \\
3 & $\begin{array}{l}\text { Two women who set up a pacifist collective and farmer's market } \\
\text { in Kyoto City. }\end{array}$ \\
4 & $\begin{array}{l}\text { Coordinator at the Kyoto Prefectural nonprofit organization } \\
\text { Partnership Centre. }\end{array}$ \\
5 & $\begin{array}{l}\text { Member of the strategic management group of a Kyoto-based } \\
\text { corporation active in, e.g., recycling food waste for biofuel in } \\
\text { small communities. }\end{array}$ \\
7 & $\begin{array}{l}\text { An organic farmer and guesthouse owner in Nantan, north of } \\
\text { Kyoto City. }\end{array}$ \\
8 & $\begin{array}{l}\text { International development manager for an indoor vertical farm } \\
\text { Fair trade coffee importer and local produce trader. }\end{array}$ \\
10 & $\begin{array}{l}\text { Founder and owner of a vegan café in downtown Kyoto. } \\
\text { Four employees of a large food cooperative in Kyoto prefecture. }\end{array}$ \\
\hline
\end{tabular}

All participants outlined their ideal food future in 2050, as well as the people to involve and issues to resolve. All three differed significantly among participants. Still, one common motivating factor for starting their seed practice was the Great East Japan Earthquake of 2011, which revealed the fragility of Japan's import-dependent food system. This focus on self-sufficiency and resilience returned in almost all future visions. Many of the visions also focused on local and personal practices, such as supporting organic farming. The transformations that participants deemed necessary to make their visions a reality ranged from large institutional change, such as implementing a basic income, to a lead-by-example approach in which participants would engage in the activities they enjoyed and hoped that people would join them. There was a noticeable difference in scope among the participants, from those focused solely on Kyoto City to those with a more international outlook. There was no consensus on what would be the scope or size of an ideal future food system to feed the Kyoto area. Finally, it turned out to be difficult for most participants at this stage to identify partners with whom they could achieve their vision. The role of the government received ambiguous responses: some initiatives benefited from government support, but many had little faith in the government's ability or willingness to help.

From the visions expressed in the individual interviews, three key themes emerged: urban and rural areas, small and large actors, social and technological innovation (Appendix 5). In terms of sustainability, the visions that emerged focused mostly on social sustainability and innovation, and less on environmental and economic sustainability.

\section{Back-casting}

The back-casting output consists of two parts: the back-casted action plans and the process outcomes measured in a postgame playing survey.

\section{Back-casting output}

The back-casting focus groups started out with the three prewritten narratives for a sustainable food future in 2050 (Appendix 5), based on the key themes that emerged from the visioning interviews: urban and rural areas, small and large actors, social and technological innovations. In the first focus group the participants chose social and technological innovation, in which they placed the emphasis on the former. Over the long term, their back-cast included institutional change, preceded by a period of civil activity to create pressure for this. Over the short term the participants planned to start by taking action in their personal lives, such as taking more time for lunch and inviting people so they would not be eating alone.

In the second focus group the participants chose the urban and rural areas-narrative, in which they placed the emphasis on integrating the two rather than connecting them. Subsequently, they worked back by planning a new department of farmer's markets in every neighborhood, for which they would set up the infrastructure in the midterm. The short term consisted of a largescale campaign to appeal to teenagers and a change in agricultural land laws enabling more opportunities for more people to produce food.

In the final focus group, the participants opted for the small and large actors-narrative, which they adjusted mostly to benefit small actors. Their back-casted plan consisted of a basic income for all citizens in the long term. In the mid-to-long-term, an FPC and an educational program should pave the way for this. The 
participants saw many opportunities for the short term, starting by making use of the workshop momentum, going to and inviting people for food related events, calling their local representatives, and carrying an extra business card to meet like-minded people based on interests and talents.

\section{Back-casting survey results}

With regard to the process effects, empathy was left out as a focus question because there was no role-playing involved. Learning about the subject through encountering new ideas proved to be very effective, with nearly all participants indicating that they heard new ideas or new approaches to existing issues. With regard to expanding people's network, the method was also quite impactful as most participants met at least two new people. Furthermore, the new ideas that participants mentioned oftentimes came from the occupations and experience of their fellow participants. Finally, the participants indicated that they felt motivated to act in two different ways: five participants saw opportunities to use the method in their daily life, and another nine participants identified new ideas that they could apply in practice. Figure 4 provides an overview of the survey results.

Fig. 4. Survey results for back-casting focus groups.

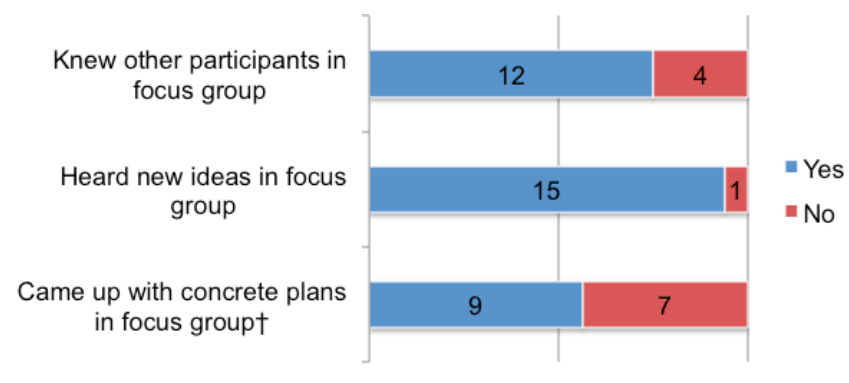

†"concrete plans" refers to concrete actions to be taken in the immediate future

\section{Gaming}

\section{Digital game}

The digital game was set up as a case of premade prototype testing. In addition to being direct feedback for the further development of the game, the suggestions that the participants registered gave some indication of their insight into the food system and certain issues that had priority for them, for example, a ceiling on local production to better approximate the real situation, include large-scale consumers such as hospitals and schools, punish waste or overproduction, and include (de) population issues. These suggestions corresponded to some key points of interest that resulted from the visioning and backcasting exercises, for example, in the case of the school lunches and (limits to) local production for local consumption.

\section{Digital game survey results}

The game's experiential process effects were measured in a postgame survey. Figure 5 shows the results of the survey conducted after the workshop. Although results vary between participants, most of the participants reported that they understood the food system and ways to intervene slightly better after the game.
Fig. 5. Survey results from the computer game. WS, workshop.

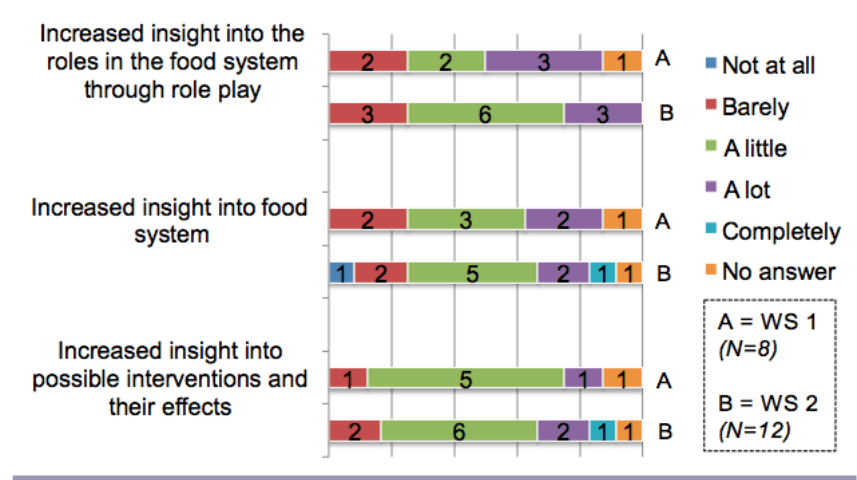

Card-based live role-playing game

In the first workshop, the budget that the teams received was 100.000 units of a fictional currency similar to yen per round, or per year in game time. In the first round, the two initiatives set up by the two FPC-teams were a certification scheme and Oyako Canteens, a parent-child community kitchen. In both cases the players spent a significant amount of time discussing the budget, and actively aimed to not spend their entire budget. In the second round, the two competing initiatives were an educational initiative targeting university students, and a scheme that would teach children about tea farming. Both initiatives were successful over two years: the tea farming scheme was the winner of round two because of its level of detail. In the final round of voting, the tea farm came out victorious as well.

To try and see if more innovative ideas could be stimulated, the budget was raised for the first round of the second workshop to 1 million yen. The two initiatives that were started in the first round were a combination of Edible schoolyard, ecolabel and research center, and a Vegetable Dating Service: connecting people to the farmers that farm their vegetables, and farmers to people with rare indigenous seeds. The former won the round because of the level of detail incorporated into its conception. In the second round, the budget was said to be limitless. The first team came up with the KodoMall (KidsMall), a department store filled with food related activities, running on a virtual currency that could only be spent by kids. The underlying aim was to revitalize lost shopping areas while at the same time creating a youth environment. The other team designed a plan for the Aori School, an educational tour plan in which youth would take tours all around Japan and help out and learn from older farmers on their farms. Although the KodoMall won the head-to-head matchup, in the final voting round, the Edible schoolyard label and research center was voted best plan of the day because of its ambitious goals and high degree of specificity (Appendix 6).

Card-based live role-playing game survey results

Figure 6 details the outcomes of the postgame surveys conducted after both workshops. In both workshops most of the participants indicated that they encountered many new ideas. Examples that participants gave had mostly to do with the initiatives on the seed cards that were new to them. The second question that addressed learning was meant to inquire about the experiential effect of the 
card-based live role-playing game. The results indicated that all but one participant had an increased level of understanding what being a member of an FPC would entail. A majority of participants in both workshops indicated that they would either "probably" or "absolutely" join an FPC if given the opportunity. This indicates a motivating effect of the card-based live roleplaying game. In each workshop two-thirds of the participants reported to at least empathize somewhat better with other people's roles. The survey results show that many people knew other participants in both workshops. However, most people knew only one other person, suggesting that they at most met six new people in workshop 1 or 10 new people in workshop 2. The survey outcomes were relatively the most ambiguous for empathy effects. Some participants reported that they felt uncomfortable representing other people while they were in the same group, or uncomfortable representing people when they were not there. Furthermore, the survey results indicate that participants increased their understanding of other people's perspectives more by actually playing with these people, rather than impersonating them.

Fig. 6. Survey results card-based live role-playing game. FPC, food policy councils; WS, workshop.

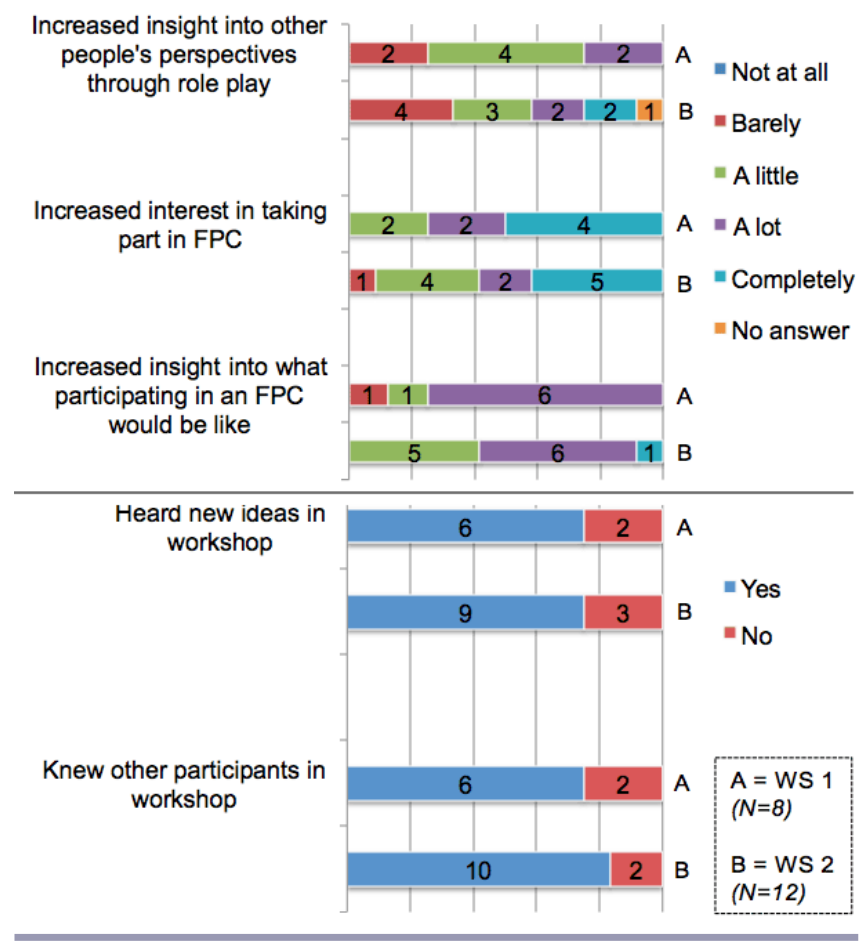

\section{Food system pathways}

To capture the variety of pathway elements that resulted from the complementary methods approach, Table 5 summarizes the most important outcomes per method. The table is structured according to every method's unique contribution to the overall methods design. The visioning included integrated notions of technological and social innovation and change, as well as specific ideas about geography (urban-rural dynamics) and the desired societal roles of different actors. In terms of making these new futures concrete, in both the back-casting and gaming sessions, the participants started thinking about how either they or their envisioned civil society effort could push for changes in practice, as far as possible given the limited time available for the processes. The inclusion of diverse seed practices from our case study, Kyoto, from elsewhere in Japan, and from around the world led to the discussion of new combinatory practices in the Kyoto food system.

\section{DISCUSSION}

The research presented in this paper investigated how existing examples of good practices, or seeds, can be used to envision novel, desirable bottom-up futures that have a high potential to become starting points for action (Bennett et al. 2016). Key elements of the presented approach are the combination of seed initiatives with a new mode of governance, the food policy council, new to the Kyoto context, and the use of different approaches to engage with these futures in very different ways, as visions that help direct efforts, as achievable action plans toward those visions, and as game-based future worlds to inhabit, play, and experiment with in order to practice with a new form of governance. Together, these combined methods aimed to offer participants diverse and complementary possibilities to explore and experiment with desired futures, to let them extend their future imaginaries, learn about the present activities and desired futures of other food system actors, and be motivated to take action toward a desired food system future.

\section{From future experimentation to action in the present}

The extension of collective future imaginaries means that people are engaging with new futures that can be enacted in the present (Jasanoff 2015). New networks and coalitions of actors who are committed to taking action are needed in order to move from experimentation with the future to enacting the new practices and modes of governance (Bennett et al. 2016). Foresight processes that target a specific policy or strategy usually have the best chance of translating their imagined futures to present day action (Vervoort et al. 2014, Hebinck et al. 2018). In the Kyoto process, many different stakeholders involved in different food practices were present, among whom were government workers and politicians with some level of decision-making power that could take the pathways forward. However, the lack of an overtly shared agenda or focused policy process arguably lowered the likelihood of the imagined futures being enacted in practice. On the other hand, the diversity of stakeholders also ensured the introduction of many new ideas about the future, and helped create new networks; most participants met at least one new person in their back-casting focus group session, and at least three in their gaming session. Participants reported learning much about the activities, plans, and interests of others, indicating new possibilities for collaboration.

Given the lack of a pre-existing strategy or policy to focus on, the food policy council as a new form of food systems governance to experiment with seems to have been the key to the organization of a new action coalition. The high number of participants that reported feeling motivated to participate in an FPC emphasizes the promise for follow-up steps beyond the futures process. The combination of learning about being in an FPC and feeling motivated to participate in one indicates the success of the applied simulation game method as a means of "practicing the future," with potential for behavioral change in the policy network (Mayer 
Table 5. Overview of sustainable food system pathway elements per method. FPC, food policy councils.

1. Visioning: goals

Main themes

Social and technological innovation

Urban and rural areas

Small and large actors

2. Back-casting (selection of examples): action points

Main themes

Social and technological innovation: longterm institutional change

Social and technological innovation: midterm reforms

Social and technological innovation: shortterm direct action

Urban and rural areas: long-term

institutional change

Urban and rural areas: midterm reforms

Urban and rural areas: short-term direct action

Small and large actors: long-term institutional change

Small and large actors: midterm reforms

Small and large actors: short-term direct action

3a. Digital game prototype: feedback

Main themes

Reflections on key local urban food system

issues that must be included as game

elements for Kyoto

3b. Card-based game: ideas

Main themes

FPC initiatives: Embodying and

experimenting with the future by developing

plans as a fictional FPC

\section{Pathway elements}

"Technological innovation by larger companies is being put to use to support social innovation ..."

"The system has found a balance between the trends of urbanization and the exodus of people from the countryside ..."

"New, ambitious and innovative farming technologies and organic local farming methods co-exist.

Their combined efforts together create a more environmentally sustainable situation ..."

\section{Pathway elements}

Introduce basic income (by policy makers); introduce right to good food (by policy makers); spread FPC Kyoto through Japan (by FPC members)

Reform educational systems (by parents and local government); introduce urban agriculture (by citizens and local policy makers)

Start growing own food (by citizens); invite others to food-related activities (by citizens); make personal business card (citizens)

Long term: zero food loss (by policy makers, producers, consumers); everyone is food literate (by Ministry of Education)

Midterm: rethink working hours (by workers and national government); subsidize farmers and restaurants that use local produce (by national government)

Short term: pass on family recipes (by grandparents); always cook and eat with at least one other person (by citizens); buy from Kyoto prefecture (by citizens)

Long term: cooking cooperatives (by neighborhood groups); vegetable growing (by school

children); restructuring Ministry of Agriculture (by policy makers)

Midterm: large supermarkets sell local fare (farmers); lobby for change at ministry and mayor's office (nonprofit organizations)

Short term: make farming cool (by farmers); become energy self-sufficient (by citizens); set up farmer support system (by nonprofit organizations)

Pathway elements

Cap on local production capacity

Large-scale consumers (e.g., schools and hospitals)

Large corporate actors (e.g., convenience store chains)

Punishment for waste or overproduction

(De)population

Pathway elements

Food education in university; Oyako Canteens (accessible children's educational canteen); Kids tea farmers program; Edible schoolyard and label; Vegetable Dating Service (app-based connection between small-scale farmer and consumer); KodoMall Kingdom (repurposed mall as agricultural fun land with own currency); Aozora Food School (sustainable food education for all citizens); local certification system for Kyoto vegetables
2009). In addition, the process uncovered a number of key people as "project champions" in line with work by D'Hondt (2012). Such champions can increase the effects of the interventions by keeping the momentum in the new networks and perpetuating their existence (Brown et al. 2013). The presence of key stakeholders including government representatives was important for creating realistic avenues for action.

The pathways generated by the complementary methods provide some concrete points of action for the new actor coalition. The visioning brought up the broadly shared ideal futures of balance in the relationships between urban and rural areas, small and large actors, and social and technological innovation. The back-casting focus groups generated many points of action, with personal tasks for participants in the short term, collective action in the midterm, and institutional reform in the long term. Finally, the FPC simulator game generated many food system transformation interventions, from a vegetable dating service to a children's mall with a special local currency. All outputs can serve as important strategies for all Kyoto food system actors that aim for urban food systems change.

\section{Limitations}

Although the outcomes of the futures process provide a ground for real-world enactment of a Kyoto FPC, time constraints have not allowed for an in-depth longer term impact assessment on action following the process. Similarly, the processes themselves were rather limited in terms of time availability, reducing possibilities for very detailed plans. Furthermore, important to note is the slight risk of missing subtle details due to cultural and language barriers inherent to conducting fieldwork in Japan. However, conducting the study in collaboration with linguistically and culturally knowledgeable local experts balanced this risk to a great extent. A final limitation is the precarious balance between control and effect in the participatory action research design. The design of this research was to focus on one set of innovative food practices and the actors involved in them, in order to closely observe practice while influencing this practice at the same time. This also complicated the distinction of possible unexpected influences on participants' views and attitudes toward Kyoto's food future. Because it can be argued that it is nearly impossible to find a control group that matches the complex urban food 
system setting of Kyoto, this method was pursued at some cost of external validity.

\section{Future research}

The study highlighted in this paper is part of wider efforts to use seed practices as the basic elements for developing novel, desirable bottom-up futures for the Anthropocene (Bennett et al. 2016, Pereira et al. 2018a, b). In this broader context, the combined use of seed practices and a new form of governance to support them is a useful innovation that highlights how niche practices can be a source for novel, desirable bottom-up futures that outline various pathways for sustainability transformations. This multimethod, seeds-and-governance model can be applied in other places and at other (national, subcontinental) levels as well. Major global initiatives like the United Nations Environment Programme (2018) are investigating possibilities for developing impactful bottom-up futures, and the operationalization of the seeds approach presented in this paper provides important clues for such efforts.

In terms of methodological development, many possibilities for broadening the scope of this approach exist. For instance, by feeding back information from The FPC Simulator game into the Let'sKyoto digital game combined with the participant feedback, the digital game environment could be developed into a tool to share the experiential learning experience with a wider audience in an accessible format (Vervoort et al. 2012). To improve the roleplaying experience, future research could experiment with group composition in terms of gender, age, and occupation, which in our case might have led to different levels of receptiveness for the role-playing setting. However, a number of other studies report positive results especially with heterogeneous groups, for example, in a neighborhood game (Gordon and Schirra 2011) or groups in conflict (Belman and Flanagan 2009).

Experimentation with different ordering and combinations of the used methods is expected to yield different results as well. Furthermore, conducting the study in countries with different governance contexts is likely to yield different results. These would be interesting on their own, or as a comparison with the outcomes in the specific governance context of Japan. More generally, the effects of using complementary futures methods could be explored further in both practice-oriented research and more controlled environments. Finally, follow-up research in a case such as this could consist of a follow-up study that tests the outcomes of the various futures interventions and of the overall action research approach. A specific focus could be the materialization of the motivation to act expressed by participants in this study, or the longer term effect of the use of the FPC simulation on food systems governance.

\section{CONCLUSION}

Our main aim was to test how innovative urban food practices can be used as a basis for imagining new food futures, through the use of multiple, complementary futures methods. Much of the futures literature in the context of sustainability focuses on large-scale, global scenarios. These outputs are important, but not tailored to the local scale. Our research adds a methodology for a bottom-up process that can open up a range of local futures. It offers a practical application of the newly proposed seeds approach by Bennett et al. (2016) while combining this approach with a focus on a new model of governance. This way, the approach integrates futures based on niche practices with futures focused on governance transformations.

We extended existing research on multimethods futures processes by combining visioning and back-casting with simulation gaming, allowing the process to combine planning for the future with practicing and experimenting with the future. From the visioning, collective desires for the future emerged. In the back-casting process, various food system actors strategized toward these visions. In the games, detailed interventions were experimented with by participants embodying the future. The complementary use of methods on the one hand, and new content and concepts (seeds and the food policy council) on the other contributed to a variety of rich and diverse shared futures containing novel elements for participants, arguably leading to extended imaginaries.

The extension of most participants' networks and the unexpected emergence of key "project champions" provide links between imagining and experimenting with futures, and present day action. Specifically, the use of a new mode of governance (the food policy council) as an organizing principle has led to action steps toward the organization of this new way to organize the urban food system. We conclude that practice-based futures processes that combine visioning, planning, and experimentation can offer fundamentally new ways to both imagine and realize desired futures from the bottom up.

Responses to this article can be read online at: http://www.ecologyandsociety.org/issues/responses. php/11014

\section{Acknowledgments:}

This research was supported by the FEAST Project (No. 14200116), Research Institute for Humanity and Nature (RIHN). We thank Stijn van Wakeren, Sander Doomen, Koen van Eijk, Gijs Witkamp, and Denzel Ellis for developing the LetsKyoto game.

\section{LITERATURE CITED}

Avin, U. 2012. Tools for building scenarios. Planning 78 (10):40-43.

Bai, X., S. van der Leeuw, K. O'Brien, F. Berkhout, F. Biermann, E. S. Brondizio, C. Cudennec, J. Dearing, A. Duraiappah, M. Glaser, A. Revkin, W. Steffen, and J. Syvitski. 2016. Plausible and desirable futures in the Anthropocene: a new research agenda. Global Environmental Change 39:351-362. https://doi.org/10.1016/ j.gloenvcha.2015.09.017

Bell, W. 1996. The foundations of future studies. Transaction, Piscataway, New Jersey, USA.

Belman, J., and M. Flanagan. 2009. Designing games to foster empathy. International Journal of Cognitive Technology 14 (2):1-11.

Bennett, E. M., M. Solan, R. Biggs, T. McPhearson, A. V. Norström, P. Olsson, L. Pereira, G. D. Peterson, C. Raudsepp- 
Hearne, F. Biermann, S. R. Carpenter, E. C. Ellis, T. Hitchert, V. Galaz, M. Lahsen, M. Milkoreit, B. Martin López, K. A. Nicholas, R. Preiser, G. Vince, J. M. Vervoort, and J. Xu. 2016. Bright spots: seeds of a good Anthropocene. Frontiers in Ecology and the Environment 14(8):441-448. https://doi.org/10.1002/ fee.1309

Brown, R. R., M. A. Farrelly, and D. A. Loorbach. 2013. Actors working the institutions in sustainability transitions: the case of Melbourne's stormwater management. Global Environmental Change 23:701-718. https://doi.org/10.1016/j.gloenvcha.2013.02.013

Crutzen, P. J. 2002. Geology of mankind. Nature 415:23.

D'Hondt, F. 2012. Visioning as participatory planning tool: learning from Kosovo practices. UN Habitat, Nairobi, Kenya.

Daffara, P. 2011. Rethinking tomorrow's cities: emerging issues on city foresight. Futures 43(7):680-689. https://doi.org/10.1016/ j.futures.2011.05.009

Davies, S. R., C. Selin, G. Gano, and Â. G. Pereira. 2012. Citizen engagement and urban change: three case studies of material deliberation. Cities 29(6):351-357. https://doi.org/10.1016/j. cities.2011.11.012

Eberhardt, R. 2016. No one way to jam: game jams for creativity, learning, entertainment, and research. Pages 34-37 in Proceedings of the International Conference on Game Jams, Hackathons, and Game Creation Events. Association for Computing Machinery, New York, New York, USA. https://doi.org/10.1145/2897167.2897181

Faldi, G., and S. Macchi. 2017. Knowledge for transformational adaptation planning: comparing the potential of forecasting and backcasting methods for assessing people's vulnerability. Pages 265-283 in M. Tiepolo, A. Pezzoli, and V. Tarchiani, editors. Renewing local planning to face climate change in the tropics. Springer, New York, New York, USA. https://doi. org/10.1007/978-3-319-59096-7 13

Food and Agriculture Organization (FAO). 2011. Food, agriculture and cities: challenges of food and nutrition security, agriculture and ecosystem management in an urbanizing world. FAO Food for the Cities multi-disciplinary initiative position paper. FAO, Rome, Italy.

Gordon, E., and S. Schirra. 2011. Playing with empathy: digital role-playing games in public meetings. Pages 179-185 in Proceedings of the 5th International Conference on Communities and Technologies. Association for Computing Machinery, New York, New York, USA. https://doi.org/10.1145/2103354.2103378

Gray, D., S. Brown, and J. Macanufo. 2010. Gamestorming: a playbook for innovators, rulebreakers and gamechangers. O'Reilly, Sebastopol, California, USA.

Gregory, W. J. 1996. Discordant pluralism: a new strategy for critical systems thinking. Systems Practice 9(6):605-625. https:// doi.org/10.1007/BF02169216

Hebinck, A., J. M. Vervoort, P. Hebinck, L. Rutting, and F. Galli. 2018. Imagining transformative futures: participatory foresight for food systems change. Ecology and Society 23(2):16. https:// doi.org/10.5751/ES-10054-230216

Jasanoff, S. 2015. Future imperfect: science, technology, and the imagination of modernity. Pages 1-33 in S. Jasanoff and S.-H.
Kim, editors. Dreamscapes of modernity: sociotechnical imaginaries and the fabrication of power. University of Chicago Press, Chicago, Illinois, USA. https://doi.org/10.7208/ chicago/9780226276663.003.0001

Kok, K., M. van Vliet, I. Bärlund, A. Dubel, and J. Sendzimir. 2011. Combining participative backcasting and exploratory scenario development: experiences from the SCENES project. Technological Forecasting and Social Change 78(5):835-851. https://doi.org/10.1016/j.techfore.2011.01.004

Kolb, D. A. 1984. Experiential learning: experience as the source of learning and development. Prentice Hall, Englewood Cliffs, New Jersey, USA.

Kraus, B. 2015. The life we live and the life we experience: Introducing the epistemological difference between "lifeworld" (Lebenswelt) and "life conditions"(Lebenslage). Social Work and Society 13(2).

Mayer, I. S. 2009. The gaming of policy and the politics of gaming: a review. Simulation \& Gaming 40(6):825-862. https://doi. org/10.1177/1046878109346456

Mayer, I., G. Bekebrede, C. Harteveld, H. Warmelink, Q. Zhou, T. Van Ruijven, J. Lo, R. Kortmann, and I. Wenzler. 2014. The research and evaluation of serious games: toward a comprehensive methodology. British Journal of Educational Technology 45(3):502-527. https://doi.org/10.1111/bjet.12067

Mayes, C. 2014. An agrarian imaginary in urban life: cultivating virtues and vices through a conflicted history. Journal of Agricultural and Environmental Ethics 27(2):265-286. https://doi. org/10.1007/s10806-013-9463-X

Ministry of Agriculture, Forestry and Fisheries. 2017. Karoribesu no todofukenbetsu shokuryou jikyuritsu [Prefectural food selfsufficiency rates] [In Japanese]. Ministry of Agriculture, Forestry and Fisheries, Tokyo, Japan [online] URL: http://www.maff.go. ip/j/zyukyu/zikyu ritu/zikyu 10. html

Mitgutsch, K., and N. Alvarado. 2012. Purposeful by design? A serious game design assessment framework. Pages 121-128 in FDG '12 Proceedings of the International Conference on the Foundations of Digital Games. Association for Computing Machinery, New York, New York, USA. https://doi. org/10.1145/2282338.2282364

Mooney, P. H., K. Tanaka, and C. Ciciurkaite. 2014. Food policy council movement in North America: a convergence of alternative local agrifood interests? Pages 229-255 in D. H. Constance, M. C. Renard, and M. G. Rivera-Ferre, editors. Alternative agrifood movements: patterns of convergence and divergence. Emerald Group, Bingley, UK. https://doi.org/10.1108/S1057-192220140000021023

Moragues-Faus, A., and K. Morgan. 2015. Reframing the foodscape: the emergent world of urban food policy. Environment and Planning A: Economy and Space 47(7):1558-1573. https://doi. org/10.1177/0308518X15595754

O'Brien, F., and M. Meadows. 2001. How to develop visions: a literature review, and a revised CHOICES approach for an uncertain world. Systemic Practice and Action Research 14 (4):495-515. 
Oda, K., C. D. D. Rupprecht, K. Tsuchiya, and S. R. McGreevy. 2018. Urban agriculture as a sustainability transition strategy for shrinking cities? Land use change trajectory as an obstacle in Kyoto city, Japan. Sustainability 10(4):1048. https://doi. org/10.3390/su10041048

Pereira, L. M., E. M. Bennett, R. (O.) Biggs, G. D. Peterson, T. McPhearson, A. Norström, P. Olsson, R. Preiser, C. RaudseppHearne, and J. Vervoort. 2018a. Seeds of the future in the present: exploring pathways for navigating towards "Good Anthropocenes." Pages 327-350 in T. Elmqvist, X. Bai, N. Frantzeskaki, C. Griffith, D. Maddox, T. McPhearson, S. Parnell, P. Romero-Lankao, D. Simon, and M. Watkins, editors. Urban planet: knowledge towards sustainable cities. Cambridge University Press, Cambridge, UK. https://doi.org/10.1017/9781316647554.018

Pereira, L. M., T. Hichert, M. Hamann, R. Preiser, and R. Biggs. $2018 b$. Using futures methods to create transformative spaces: visions of a good Anthropocene in Southern Africa. Ecology and Society 23(1):19. https://doi.org/10.5751/es-09907-230119

Popper, R. 2008. How are foresight methods selected? Foresight 10(6):62-89. https://doi.org/10.1108/14636680810918586

Qu, S., and J. Dumay. 2011. The qualitative research interview. Qualitative Research in Accounting \& Management 8(3):238-264. https://doi.org/10.1108/11766091111162070

Robinson, J., S. Burch, S. Talwar, M. O'Shea, and M. Walsh. 2011. Envisioning sustainability: recent progress in the use of participatory backcasting approaches for sustainability research. Technological Forecasting and Social Change 78(5):756-768. https://doi.org/10.1016/j.techfore.2010.12.006

Rupprecht, C. D. D. 2017. Informal urban green space: residents' perception, use, and management preferences across four major Japanese shrinking cities. Land 6(3):59. https://doi.org/10.3390/ land6030059

Scherb, A., A. Palmer, S. Frattaroli, and K. Pollack. 2012. Exploring food system policy: a survey of food policy councils in the United States. Journal of Agriculture, Food Systems and Community Development 2(4):3-14. https://doi.org/10.5304/ jafscd.2012.024.007

Schiff, R. 2008. The role of food policy councils in developing sustainable food systems. Journal of Hunger and Environmental Nutrition 3(2-3):206-228. https://doi.org/10.1080/19320240802244017

Seto, K. C., and N. Ramankutty. 2016. Hidden linkages between urbanization and food systems. Science 352(6288):943-945. https://doi.org/10.1126/science.aaf7439

Smit, B., and J. Wandel. 2006. Adaptation, adaptive capacity and vulnerability. Global Environmental Change 16:282-292. https:// doi.org/10.1016/j.gloenvcha.2006.03.008

Soria-Lara, J. A., and D. Banister. 2017. Participatory visioning in transport backcasting studies: methodological lessons from Andalusia (Spain). Journal of Transport Geography 58:113-126. https://doi.org/10.1016/j.jtrangeo.2016.11.012

Steger, M. B. 2008. The rise of the global imaginary: from the French Revolution to the global war on terror. Oxford University Press, Oxford, UK.
United Nations. 2015. World urbanization prospects: the 2014 revision ( $S T / E S A / S E R . A / 366$ ). United Nations, New York, New York, USA.

United Nations Environment Programme. 2018. Global Environment Outlook 6: Healthy planet healthy people. Cambridge University Press, Cambridge, UK. https://doi.org/10.1017/9781$\underline{108627146.001}$

Van Vliet, M., K. Kok, A. Veldkamp, and S. Sarkki. 2012. Structure in creativity: an exploratory study to analyse the effects of structuring tools on scenario workshop results. Futures 44 (8):746-760. https://doi.org/10.1016/j.futures.2012.05.002

Vervoort, J. M., R. Bendor, A. Kelliher, O. Strik, and A. E. R. Helfgott. 2015. Scenarios and the art of worldmaking. Futures 74:62-70. https://doi.org/10.1016/j.futures.2015.08.009

Vervoort, J. M., K. Kok, P.-J. Beers, R. van Lammeren, and R. Janssen. 2012. Combining analytic and experiential communication in participatory scenario development. Landscape and Urban Planning 107(3):203-213. https://doi.org/10.1016/j.

landurbplan.2012.06.011

Vervoort, J. M., P. K. Thornton, P. Kristjanson, W. Förch, P. J. Ericksen, K. Kok, J. S. I. Ingram, M. Herrero, A. Palazzo, A. E. S. Helfgott, A. Wilkinson, P. Havlík, D. Mason-D'Croz, and C. Jost. 2014. Challenges to scenario-guided adaptive action on food security under climate change. Global Environmental Change 28:383-394. https://doi.org/10.1016/j.gloenvcha.2014.03.001

Voros, J. 2006. Introducing a classification framework for prospective methods. Foresight 8(2):43-56. https://doi. org/10.1108/14636680610656174

Wigginton, N. S., J. Fahrenkamp-Uppenbrink, B. Wible, and D. Malakoff. 2016. Cities are the future. Science 352(6288):904-905. https://doi.org/10.1126/science.352.6288.904

World Wildlife Fund Japan. 2016. Sennen no toshi kara, tsugi no sennen no mirai he; ecorojikaru futtopurinto chiiki ban ripoto Vol. 1 (From the 1000 year city, to the next 1000 years; Regional ecological footprint report Vol. 1). World Wildlife Fund Japan, Tokyo, Japan. 


\section{Appendix 1}

Back-casting survey (English version)

Your network

1a. Were there people in this workshop that you had already met before? o No

oYes, I knew the following people:

Name

Our connection

2. Did any new ideas come up in the workshop?

o No

o Yes, the following ideas came up in the workshop:

3. Did any concrete new plans come out of this workshop? o No

o Yes, the following plans have come out of this workshop:

3. How would you describe your personal experience of this workshop?

4. Was this method new to you and do you think you might use it in your own work? 


\section{APPENDIX 2}

Game surveys

- Let's Kyoto survey (English version)

1. The game improved my insight in how the food system works:

$\begin{array}{lllll}0 & 0 & 0 & 0 & 0 \\ \text { Notatall } & \text { Barely } & \text { A little } & \text { Alot } & \text { Completely }\end{array}$

2. The role play in the game improved my insight in the roles in the foodsystem:
(
Notat all Barely
0
0
0
A little A lot Completely

3. The game gave me insights in different possible interventions in the local food system and their effects:
0
0
0
0
0
Not at all Barely
A little
A lot
Completely

4. If I could add another intervention to the game, it would be the following:

- The FPC Simulator survey (English version)

1. The game gave me a good idea of what it is like to be in a Food Policy Council:
0
0
0
0
0
Notatall Barely Alittle Mostly Completely

2. After playing the game, I am interested in taking part in a Food Policy Council:

0

0

0

0

0

Not at all Probably not

A little

Probably

Absolutely

3. If I would be in a Food Policy Council for Kyoto prefecture, I would want it to do the following things:

4. I heard new ideas in this workshop:

O No

0 Yes, the following:

5. The role playing in the game gave me a greater insight into other people's perspective:

0

0

0

0

0

Not at all Barely

A little

A lot

Completely 


\section{APPENDIX 3}

Gameplay \& rules for FPC Simulator (English version)

You and your group are the new Food Policy Council (FPC) of Kyoto prefecture. The mission of your FPC is to make Kyoto's prefecture's more environmentally sustainable and socially just, and stimulate local economic development. Let's play!

- STEP 1 - INTRODUCTION AND ROLES

The game starts with the players filling out the role cards from their own role. In round 1 , the players play their own roles. In round 2 , the players introduce themselves with their own name, but otherwise assume the role of someone else at the table by using each other's role cards.

- STEP 2 - SET FPC AGENDA

Every player has 3 main issues on their role card that they think the FPC should address. During the introduction round, the facilitator writes down each player's top issues on the FPC agenda sheet. Afterwards, the main themes on the agenda are shortly discussed together. After determining the agenda, a chairperson should be appointed who oversees the budget, does the writing and leads the FPC's discussion.

- STEP 3 - DRAWING A SET OF INTITATIVES

Now that the FPC is in business, a timer starts counting down 45 minutes. It's time to support food initiatives in Kyoto prefecture that do good work. The FPC also looks outside of the prefectural borders and outside of Japan for inspiration. The FPC draws one card from each deck of initiatives: green $=$ Kyoto, red $=$ Japan and yellow $=$ world. First, shortly discuss the potential of the three initiatives.

- STEP 4 - SUPPORTING THE INITIATIVES

Each round represents a period of one year, for which the FPC gets 1000.000 yen from the bank. This money does not all have to be spent in one round. To support its initiative(s), the FPC should make a plan, drawing possible inspiration from the intervention list and involving as many roles as possible. Write the intervention down on an activity card, and allocate a budget to it. The facilitator gives the FPC a feasibility rating, based on 1) feasibility of plan 2) budgetting, 3) inclusion of all different roles and 4) ambition. The FPC can shortly plea to raise this rating. Once it's set, roll the 10 -sided dice. A score within the feasibility rating means success, one above it means failure. Move on to the next round and draw 3 new initiatives. In case of failure, first take some time and spend some budget to make the failure right. Then roll the dice again and try to get to success. A final step at the end of each round is rolling for disaster: roll the dice once more. If you get 1 , roll again to find out which disaster off the disaster list has hit you. You have to deal with this disaster in the next round.

- STEP 5 - TIME'S UP

After 45 minutes of playtime, the different FPCs in the game shortly present their agenda and set of interventions to one another. The team with the highest number of successful initiatives wins a prize! 


\section{APPENDIX 4}

Seed initiatives included in the FPC Simulator card-based table top live roleplaying game

\section{World}

- Center for ecoliteracy - a center that aims to stimulate education for sustainable living.

Source: https://goodanthropocenes.net/2016/04/20/center-for-ecoliteracy/

- Santropol roulant - a Montreal-based community food initiative. Source: https://goodanthropocenes.net/2016/04/14/santropol-roulant/

- Retuna Altebruksgalleria - a mall and cafe dedicated entirely to repaired and "upcycled" goods.

Source: https://makewealthhistory.org/2017/03/22/the-worlds-first-mallfor-recycled-goods/

- Philippi horticultural area $-3000 \mathrm{~m} 2$ area of land that supplies half of Cape Town's fresh produce.

Source: https://goodanthropocenes.net/2016/07/23/philippi-horticulturalarea-food-farming-campaign/

- Re:farm - project in the US dedicated to growing food in, by and for the community.

Source: $h t t p: / / w w w . r e v i s i o n . c o o p / p r o g r a m s /$

- Sustain ability challenge - 6-month challenge stimulating people in the UK to live more sustainably. Source: https://goodanthropocenes.net/2015/04/08/sustain-abilitychallenge-and-live-better-challenge/

- Union kitchen - culinary startup incubator. Source: $h t t p: / / w w w . u n i o n k i t c h e n d c . c o m$

- Farm hack - an open source software tool for small-scale resilient agriculture.

Source: https://goodanthropocenes.net/2016/08/02/farm-hack-open-sourcetools-for-small-scale-resilient-agriculture/

- De Ceuvel - a circular business park in Amsterdam Source: http://www.circle-economy.com/grand-opening-new-office-deceuvel/

- Instock restaurants - Dutch restaurant concept that only serves food that would otherwise be wasted.

Source: $h t t p s: / / w w w . i n s t o c k . n l / e n / q u e s t i o n /$

Japan

- Mother's radiation lab - radiation measuring lab set up by mothers in Fukushima.

Source: http://www.iwakisokuteishitu.com/english/aboutus.html

- Satoyama initiative - initiative seeking new ways to preserve traditional Satoyama landscapes.

Source: https://goodanthropocenes.net/2015/02/06/tribal-parks-2/

- Pasona HQ urban farm - urban farm integrated in Pasona's HQ in Tokyo. Source: https://goodanthropocenes.net/2016/05/16/urban-office-urbanfarm/ 
- Fujisawa smart town - high tech sustainable smart town concept in Fujisawa, initiated by Panasonic.

Source: https://panasonic.net/es/solution-works/fujisawa/

- Edible schoolyard - program that promotes educational vegetable gardens for schools.

Source: http://www.edibleschoolyard-japan.org

- Chiba ecofeed eggs - range of eggs produced in a food recycling loop process in Chiba prefecture.

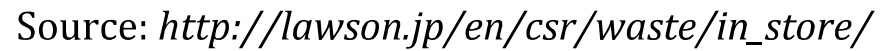

- Food bank Kagoshima - Food bank based in Kagoshima.

Source: https://www.facebook.com/pg/foodbank.k/about/?ref=page_internal

- Oyako shokudo - a parents and children's cafeteria in Minamisoma city. Source: http://www.japanfs.org/en/news/archives/news_id035771.html

- Takahata kyosei project - project in Takahata town promoting local consumption and self-sufficiency. Source: http://www.japanfs.org/en/news/archives/news_id035645.html

- Bio coke - solid fuel produced by Kobe city government in collaboration with Starbucks and Kindai university.

\section{Kyoto}

Source: http://www.japanfs.org/en/news/archives/news_id035802.html

- Mothernet food education - foundation for "neo food education". Source: https://www.food-edu.com/新-食育-neo-food-education/

- Kyoto farmer's market - bi-weekly farmer's market in Kyoto city. Source: https://www.facebook.com/kyotofarmersmarket/

- Kyoto's kodomo shokudo - organizations where children can eat and learn. Source: http://www.asahi.com/ajw/articles/AJ201607200014.html

- Kyoto eco money - a special currency that can be earned by sustainable behavior.

Source: http://www.japanfs.org/en/news/archives/news_id031037.html

- Green consumer guide - network and online platform of green businesses in Kyoto prefecture set up by an NPO.

Source: http://www.japanfs.org/en/news/archives/news_id025820.html

- Food miles label - a label that displays food miles and CO2 emissions. Source: http://www.japanfs.org/en/news/archives/news_id028907.html

- Amita circular museum - a museum displaying various projects of AMITA corporation.

Source: http://fudenkan.jp

- Saka no tochu - a Kyoto based distributor of vegetables grown without synthetic pesticides or chemical fertilizers.

Source: http://www.on-the-slope.com/english

- Spread - vertical lettuce and leafy greens farm in Kameoka.

Source: http://www.spread.co.jp/en/sustainable-farming/

- Nantan farmer's cooperative - an organic and partly self-sufficient farmer's cooperative.

Source: http://www.tukaisutejidai.com 


\section{APPENDIX 5}

Visioning narratives

\section{Social and technological innovation}

"Technological innovation by larger companies is being put to use to support social innovation. From a social perspective, people take pride in their produce, their recycling activities, cooking and other activities related to the food system. Traditional cooking methods are preserved and passed on to the next generation, but in addition to this people have the "food literacy" to make their own decisions and cook the food they feel like. In schools, the school lunches are safe and high quality. All food is safe to eat, especially food that is served to children. Food education is part of the school curriculum, and even university students and adults have opportunities for continued learning about food. Online tools enable people to organize easier into consumer collectives, sales platforms or educational communities. Furthermore, the food system has become less wasteful as a result of a combination of better social systems and technological innovation that succeeds in closing material and energy loops."

\section{Urban and rural areas}

"The system has found a balance between the trends of urbanization and the exodus of people from the countryside. Young people that are interested in becoming farmers feel motivated and supported -with tools and knowledge- to move (back) to the countryside. They are able to stay connected to the city by way of new technologies. New ways of economically successful food activities, like "beyond organic" techno-farming, directs sales on farmers markets and profitable re-use of waste have become standard practice. They make the production chain more transparent and connect consumers more directly to the food they buy and eat. Because of this newfound sustainable balance, both the natural resources and the natural landscape of Japan are protected and preserved. A steady market share for local food, produced within Japan or even closer to people's own home, makes food supply more secure, generates an income within Japan and connects people to the food they eat."

\section{Small and large actors}

"New, ambitious and innovative farming technologies and organic local farming methods co-exist. Their combined efforts together create a more environmentally sustainable situation. It also enables a preservation of traditions and local food heritage, like Kyo-yasai heirloom vegetables, while also fuelling innovation that discovers new ways to further improve Kyoto's food system. Larger and smaller companies co-exist as well, and in all cases their production chain is transparent to all actors involved. The government actively addresses sustainability issues and listens to the needs of inhabitants with regards to food. This leads to people trusting the government to support both them and their citizen initiatives. The coordinated efforts of these actors together, as well as an increased knowledge of food among a new generation of consumers, changes food demands. Private companies embrace concepts like clear labelling and certification, as well as local produce, to meet this new demand." 


\section{APPENDIX 6}

Example FPC plan

"Kodomall kingdom" (workshop 2)

\begin{tabular}{|c|c|c|}
\hline \multicolumn{3}{|c|}{ Round 1} \\
\hline Seed cards & \multicolumn{2}{|l|}{ World: Recycle mall (ReTuna) in Sweden } \\
\hline & \multicolumn{2}{|l|}{ Japan: Takahata co-existence project } \\
\hline & \multicolumn{2}{|c|}{ Kyoto: Children's cafeteria (Kodomo Shokudo) } \\
\hline Brainstorm & \multicolumn{2}{|c|}{ Make the neighbourhood eatery fashionable as "children's cafeteria". } \\
\hline & \multicolumn{2}{|c|}{ If you go help out in the field, you will receive a meal ticket. } \\
\hline & \multicolumn{2}{|c|}{ Food tickets are for children only. } \\
\hline & \multicolumn{2}{|l|}{ Parent-child participation is possible in the field. } \\
\hline & \multicolumn{2}{|c|}{$\begin{array}{l}\text { Activate shopping district at school curriculum and connect to } \\
\text { children's cafeteria. }\end{array}$} \\
\hline & \multicolumn{2}{|c|}{ Use shops in local shopping areas. } \\
\hline & \multicolumn{2}{|l|}{ Learn with the help of the town } \\
\hline & \multicolumn{2}{|c|}{$\begin{array}{l}\text { Connect production and consumption with digital signage in a public } \\
\text { place. }\end{array}$} \\
\hline & \multicolumn{2}{|c|}{$\begin{array}{l}\text { Buy empty shopping mall and make a place for children's food } \\
\text { education that also revitalizes the neighbourhood }\end{array}$} \\
\hline \multirow[t]{10}{*}{$\begin{array}{l}\text { Plan }+ \\
\text { budget } \\
\text { (no limit) }\end{array}$} & $\begin{array}{l}\text { Shopping centre infrastructure development: } \\
\text { restaurant; greengrocer; tofu shop; fish; } \\
\text { miscellaneous goods }\end{array}$ & 9 million \\
\hline & $\begin{array}{l}\text { Mutual communication system (connect } \\
\text { production and consumption, digital signage) }\end{array}$ & 3 million \\
\hline & Operating cost & 7.2 million \\
\hline & Farm (10a) in shopping area & 10 million \\
\hline & Transportation expenses, conference fee & 2 million \\
\hline & Personnel expenses (3 staff members) & 12 million \\
\hline & Expert farming consultant & 2.4 million \\
\hline & Total expenses (no limit) & 45.6 million \\
\hline & Success rate & $85 \% \Rightarrow$ success \\
\hline & Disaster & None \\
\hline \multicolumn{3}{|c|}{ Round 2} \\
\hline Seed cards & \multicolumn{2}{|l|}{ World: Union Kitchen } \\
\hline & \multicolumn{2}{|l|}{ Japan: Chiba ecofeed eggs } \\
\hline & \multicolumn{2}{|l|}{ Kyoto: Eco Money } \\
\hline Brainstorm & \multicolumn{2}{|c|}{ Make the mall into a place for children's vocational experience } \\
\hline & \multicolumn{2}{|c|}{$\begin{array}{l}\text { Make a playground (free space, with activities such as movie } \\
\text { screenings, workshops, bouldering). }\end{array}$} \\
\hline
\end{tabular}




\begin{tabular}{|c|c|c|}
\hline & \multicolumn{2}{|c|}{ Make children's currency which can only be spent in Kodomall } \\
\hline & \multicolumn{2}{|c|}{ Parents should be barred from taking and spending the currency } \\
\hline & \multicolumn{2}{|c|}{ Encourage and support children's start-up shops in the mall } \\
\hline & \multicolumn{2}{|c|}{ Develop systems, mail order and information dissemination. } \\
\hline & \multicolumn{2}{|c|}{ Thinking about 'turning' the economy } \\
\hline \multirow[t]{4}{*}{$\begin{array}{l}\text { Plan }+ \\
\text { budget } \\
\text { (no limit) }\end{array}$} & $\begin{array}{l}\text { Expand KodoMall with restaurant }+ \\
\text { multipurpose room (food and movie } \\
\text { theater, pool, exercise) }\end{array}$ & 100 million \\
\hline & Development of KodoMall currency & 8 million \\
\hline & $\begin{array}{l}\text { Development of distribution system for } \\
\text { produce from the mall }\end{array}$ & 10 million \\
\hline & Total expenses & 118 million \\
\hline \multicolumn{3}{|c|}{ Time up - game ends } \\
\hline
\end{tabular}

